\title{
How Lifestyle Can Improve Health Expenses
}

\author{
Roberto Verna* \\ Department of Experimental Medicine, Sapienza University of Rome, President, World Association of Societies of Pathology and
} Laboratory Medicine

Received: May 01, 2018; Accepted: May 31, 2018; Published: June 06 , 2018

*Corresponding author: Roberto Verna, Department of Experimental Medicine, Sapienza University of Rome, President, World Association of Societies of Pathology and Laboratory Medicine, E-mail: roberto.verna@uniroma1.it

\section{Abstract \\ Physical activity is important for the prevention of many diseases and to improve the conditions of sick people. "Exercise is medicine" is the new address for prevention and therapy. \\ The boys also benefit of the sport activity for their psychological maturation.}

In addition, there is the damage from poor nutrition, alcohol dependence and the overuse of pharmacologically active substances, misuse of drugs, even those permitted.

It is therefore necessary to increase the quantity/quality of time devoted to physical activity, both at school and outside school, but above all, it is vital the dissemination of knowledge of the problem.

A widespread information / training, along with a sport and proper medical supervision into every type of school, would lead to a sharp reduction in public spending, much higher than the 80 million of which we have just spoken, with an almost negligible investment.

The ideal would be to set up in School a course of education to health, with the principles of nutrition and physical activity, in order to improve the lifestyles and reduce health spending through health education, proper nutrition and sports activities. 1-2 hours a week would be enough to communicate to children, and indirectly their families and the families of the future, what are the criteria for a healthy life.

It is however, necessary to have suitably qualified teachers for the treatment and dissemination of health prevention principles of proper nutrition and the correct approach to sports activities. A specific training should be therefore held in the University. Health education cannot be done by the science teachers or those of motor sciences, alone; they must have a physician specially trained to coordinate, perhaps in co-presence, the interventions.

\section{Introduction}

One of the most important achievements of medicine over the past two decades is the role of exercise in maintaining and improving health [1]. The current situation, in fact, confirms that the main risk for health is sedentary, that causes 2 million deaths per year in the world. Physical inactivity is responsible or at least favors several pathologies and regular physical activity is essential for prevention [2].

In 2018, the estimated Italian Public Health spending will reach around 115 billion euro, 2.0\% increase if compared to 2015. In 2012 it was 111 billion, equivalent to 7\% of GDP (about 1,867 euro per year per inhabitant). Health expenditure is growing but, news of these days, in Italy the average duration of life, even if only slightly, is coming down.

Does it mean that, despite the huge professional and financial commitment, the resources are badly or not adequately employed, or is it just the result of the increase in costs? In any case, although much lower than that of other major European countries, it is necessary to find new ways to reduce health care spending.

The linear cuts made until now were strongly, and rightly, disputed because they do not guarantee an improvement of health; indeed, they are likely to worsen the resulting further increase in costs. It is, in fact, necessary to start a path to appropriateness, but this cannot be just a term; we need a strategy shared with health stakeholders.

Prevention is certainly the best way to rationalize spending and thus reduce it; but we all know that proper prevention can give long-term results, although it certainly leads to a substantial savings, at present risks only to be a cost; and resources seem exhausted.

It is, therefore, necessary to decide whether to run after the disease trying to patch the most damage created by it, spending as little as possible or, rather, do some investment, perhaps in new technologies, especially diagnostics, to reduce the occurrence of disease. Or more simply, to try to get less sick.

Physical inactivity is a health risk, because it produces 2 million deaths / year worldwide. In particular, physical inactivity favors the $10-16 \%$ of cases of breast cancer, colon cancer and diabetes and $22 \%$ of heart attacks. Regular physical activity is thus critical for prevention.

The health benefits brought by the change in lifestyle habits are proven by a 25 -year study in which it was shown that the change in lifestyle has reduced deaths from cardiovascular disease (-68\%), stroke (-73\%), cancer (-44\%).

A more active lifestyle would lead to the prevention of at least 2 million premature deaths and 20 million DALYs (DisabilityAdjusted Life Year) in the world.

Many diseases are caused by sedentary: Overweight, Obesity, Type II diabetes, cardiovascular disorders (heart attack, 
myocardial infarction, stroke, heart failure), Venous failure, Osteoporosis, Arthritis, Hypertension, Increased cholesterol and triglyceride levels in the blood, Colon and breast cancer. But the gold medal belongs to obesity, that can be classified as follows: Mild obesity (excess of 20-40\%), Moderate Obesity (40-100\%), Severe Obesity (>100\%). For five diseases it has been proven the relationship between physical activity and health benefits: cardiovascular disease, stroke, colon cancer, type II breast cancer and diabetes. An expanded list of diseases caused by sedentary lifestyle includes: overweight, obesity, diabetes type II, cardiovascular disorders (heart attack, myocardial infarction, stroke, heart failure, high blood pressure, venous insufficiency), osteoporosis, arthritis, increased blood cholesterol and triglyceride levels, colon and breast cancer. All diseases that, once arisen, tend to become chronic and must be kept under constant health control and appropriate care.

It was calculated that increasing only by $1 \%$ of the number of active people, the save in health care spending would be 80 million euro per year.

Obesity is the excess of fat mass. But it is also important to differentiate between central and peripheral obesity, since the critical adipose depot is the visceral one.

Central obesity is associated with increased incidence of complications: Metabolic disorders (diabetes and/or carbon monoxide intolerance, dyslipidemia, hyperuricemia), Cardiovascular (hypertension, ischemic heart disease and cardiac failure), Systemic (osteoarthritis, colon cancer, respiratory failure, cholelithiasis, etc.).

A particular note deserves childhood obesity: many millions of kids are seriously overweight, caused by the increased time with television, the intake of calories with junk food, the reduced physical activity $[3,4]$. Also chocolate needs a particular note: considered at high caloric content, can be utilized without problems in due amount, with several interesting goals [5].

About $50 \%$ of obese children over the age of 6 become obese by adult compared to $10 \%$ of non-obese children of the same age.

In obese adolescents this percentage rises to $70 \%$ and exceeds $80 \%$ if even one of the parents is obese (Table I).

Table I: Development of obesity in adulthood related to obesity in childhood

\begin{tabular}{|c|c|}
\hline Age & \% PERSISTENT RISK OF OBESITY IN ADULT \\
\hline Obesity $6 \mathrm{y}$ & $25 \%$ obese adult \\
\hline Obesity $12 \mathrm{y}$ & $75 \%$ obese adult \\
\hline
\end{tabular}

According to these data, the presence of obesity in adolescence is predictive of a greater development of cardiovascular events in adulthood, although at this time of life a normal body weight has been achieved [6].

Obesity has also a regional breakdown, at least in Italy. This is mainly due to nutritional and lifestyle habits (Table II).
Table II: Childhood obesity in Italy compared between males and females in different Country areas

\begin{tabular}{|c|c|}
\hline Childhood obesity prevalence in Italy & \\
Males & Females \\
\hline Center/south areas $22 \%$ & $35 \%$ \\
\hline Northern areas $13 \%$ & $10 \%$ \\
\hline
\end{tabular}

\section{Globesity}

The problem of obesity is widespread in the world. In USA the obesity rate is higher than $15 \%$ and reaches more than $30 \%$ in some States, but it is not the only Country that faces problems with weight excess. In Figure 1 is shown the difference between males and females as to their shape (Obesity, Overweight, Healthy weight) in different years. It is easy to see that the percent of overweight and healthy weight is decreasing during the last 10 years, while the percent of obese is increasing in both males and females (Figure 2).

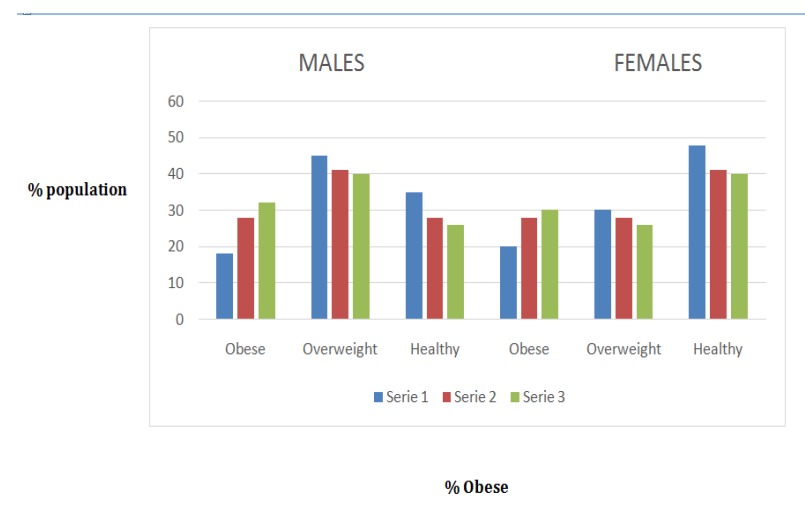

Figure 1: Obesity in percent of population, growing in different years. Column 1: 1995; Column 2: 2011-12; Column 3: 2012-16

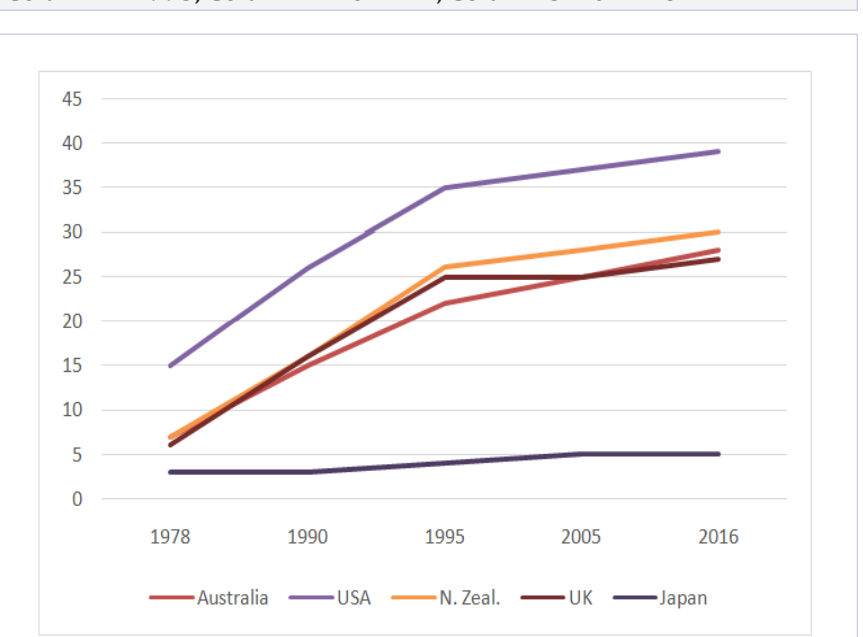

Figure 2: Shows that the trend is confirmed in Countries with western habits, but not in Japan, where obese people did not increase

Exercise is a Powerful Boost to GH Production

Aging and obesity are associated with a reduction in $\mathrm{GH}$ 
production. Then the fundamental question is the following: is Obesity that induces Aging or is Aging that makes you Fat?

The answer is that fat infiltration is a natural part of the aging process. By aging, our muscles gradually begin to shrink and this reduces the speed at which we burn calories: in fact, more muscle tissue we have, more calories we consume. When we lose muscle tissue, our ability to burn fat diminishes and we begin to add fat to our structure.

It can be described as "The Silent Invader".

If it is physiological that fatty tissue replaces the muscle during the age, it is essential to keep the muscle system active, to delay the process and prevent fat from accumulating beyond measure as well as to reduce the attack of free radicals [8].

So, physical activity is important for health. But what about sport?

Sport is a particular aspect of physical activity. It is very helpful for wellness if carefully trained; if not, it can be dangerous. The dangers come from several different points: wrong or excessive training, use and misuse of drugs or supplements, doping [9-12].

Use or misuse of drugs. Athletes take drugs for several purposes (Table III).

\begin{tabular}{|c|c|}
\hline Table III. & PURPOSE \\
\hline To improve athletic performance & $\begin{array}{c}\text { Creatine; Linear and } \\
\text { Branched Amino acids }\end{array}$ \\
\hline $\begin{array}{c}\text { For physical recovery in situations of } \\
\text { heavy athletic engagement }\end{array}$ & Ergogenic aids \\
\hline $\begin{array}{c}\text { To reintegrate losses due to intense } \\
\text { physical effort }\end{array}$ & Vitamins and Minerals \\
\hline To protect from oxidative damages & Vitamins and Antioxidants \\
\hline
\end{tabular}

In a survey of some time ago, the $65-70 \%$ of 8000 athletes confirmed the use of allowed medications according to (Table IV).

\begin{tabular}{|c|c|}
\hline \multicolumn{2}{|l|}{ Table IV. } \\
\hline Type of medication declared & \\
\hline Nonsteroid anti-inflammatory drugs & $35 \%$ \\
\hline Vitamin supplements & $20 \%$ \\
\hline Herbal / homeopathic products & $1,5 \%$ \\
\hline Supplements (salts, amino acids, etc.) & $17 \%$ \\
\hline
\end{tabular}

Is the use of supplements safe? Unfortunately, scientific demonstrations of effectiveness, proper information about body and performance action, a certainty of the content of the products, are missing. The risks are health hazards, commercial fraud and positivity to anti-doping tests.

Doping is much more widespread than can be thought and concerns all sports, both professional and amateurly. The damages that can cause to health are many and serious $[13,14]$.
All emergency physicians should be aware of the problem, not to underestimate it and recognize any symptoms (Verna, unpublished results).

In the 2000s many police operations (carabinieri and financial police) led to the seizure of large quantities of prohibited substances that were illegally traded. In particular, during the "Hercules" operation, the wide variety of the pharmaceutical substances found, as well as their amount, that led the total value around 8.970.000,00 euro, was really surprising. In table $V$ the

Table V: List of the pharmaceutical substances seized during the "Hercules" operation

\begin{tabular}{|c|c|c|}
\hline Aldactone & HomeocurTesterset & Saizen \\
\hline $\begin{array}{c}\text { Anapolon Tablet } \\
\text { Oksimetolon }\end{array}$ & Humolin & Schering \\
\hline Andriol & Jintropin & Synflex \\
\hline Benadon & Kadiur & Somatostatina \\
\hline Clomiphene Citrate & Kriptocur & Spasmobroncal \\
\hline Deca-Durabolin & Isopuramin & Spiropent \\
\hline Dianabol & Lipostabil & Sustenon \\
\hline Depo Medrol & Masteron & Tad 600 \\
\hline Efedrina Level & Metadienon & Tioside \\
\hline Epargriseovit & Metanabol & Ti-Tre Liotironina \\
\hline Esiclene & Monores & TestexElmuProlongatum \\
\hline Estrumate & Napopsin & Testosterone Cypionate \\
\hline Eutirox & Neoton & Testoviron \\
\hline Extraboline & Nespo 60 & Testovis \\
\hline Feldene & Novaldex Tamoxife & Transmetil \\
\hline Finaject & Parabolan & Ventipulmin Citrate \\
\hline Finasteride & Placentex & $\begin{array}{c}\text { Virormone Testosterone } \\
\text { Propinate }\end{array}$ \\
\hline Ganabol & Primobolan & Winstrol \\
\hline Genotropin & Profasi Hp & \\
\hline GhUmatrope & ProcarFinasteride & \\
\hline \multirow[t]{2}{*}{ Lasix } & Proviron & \\
\hline & Restandol & \\
\hline
\end{tabular}

complete list of the substances seized is shown. Obviously, in order not to be identified, both the sellers and the buyers used jargon terms for the commerce of the prohibits substances. A list of these jargon terms, registered during telephone tapping (Carabinieri for Health- N.A.S.) is shown in table VI.

\section{Factors Favoring the Spread of Doping}

Often parents are the ones who claim from their children a champion sports career, also accepting doping if it can serve to realize their dreams. Sometimes, a young person receives doping but no one around him realizes it. 
Table VI: Jargon terms used for the commerce of prohibited substances

\begin{tabular}{|c|c|}
\hline Ephedrine & Mau-Wang \\
\hline Winstrol & double V - dresses - STROMBA \\
\hline Ganabol & (for veterinary use only) \\
\hline Deca & those with the yellow cap - burned \\
\hline Andriol & the motorbike \\
\hline Decadurabolin & the cars \\
\hline Nandrolone Decanoate & trousers \\
\hline Proviron & lat machine \\
\hline Oxandrolone & smoke - chocolate \\
\hline Hashish & (the cold»-the ice-cool proteins-tyres \\
\hline GH & Pecaffeinated \\
\hline Primobolan & PRO \\
\hline Proviron & «those with the blu box» \\
\hline Testovis & \\
\hline
\end{tabular}

An additional problem is the medicalization of some sport facilities. Some gyms are a mix of space structures and backpacks of pharmacies. You can find everything and almost nothing is harmless.

Formerly I have reported that Sport is a particular aspect of physical activity: very helpful for wellness if carefully trained, harmful if not. It is therefore important, before approaching Sport, to Know One's Numbers, such as Body Mass Index (BMI).

The calculation of BMI is based on height and weight: wt. (kg) $\div$ ht. $\left(\mathrm{m}^{2}\right)$;

- Doesn't account for gender, muscle mass, or frame size;

- Health risks increase with the increase of BMI;

- Waist Circumference (WC).

The Goal for Men is $\leq 40$ inches, (ideal $<37$ inches), while for Women is $\leq 35$ inches, (ideal $<33$ inches). According to BMI it is possible to draw a classification of obesity, as follows (Table VII)

\begin{tabular}{|c|c|}
\hline Table VII. & \multicolumn{1}{|l|}{} \\
\hline Weight Category & BMI \\
\hline Underweight & $<18.5$ \\
\hline Healthy Weight & $18.5-24.9$ \\
\hline Overweight & $25.0-29.9$ \\
\hline Obesity (class I) & $30.0-34.9$ \\
\hline Obesity (class II) & $35.0-39.9$ \\
\hline Obesity (class III) & $\geq 40.0$ \\
\hline $\begin{array}{c}\text { Modified from Archives of Internal Medicine. } \\
\text { 1998; 158: 1855-67 (no author listed) }\end{array}$ \\
\hline
\end{tabular}

After this long introduction to the problem, is it possible to make a prevision for the future?

\section{The Cost of Disease and the Saving of Prevention}

Sports activities are important for preventing many pathologies and improving conditions for sick people. Children, in particular, also benefit from sports activity for their psychic maturation (European Youth Portal, Published: Fri, 16/05/2014 16:40; Global Strategy on Diet, Physical Activity and Health, WHO portal, 9 February 2017).

Enormous are the damages due to incorrect nutrition, use and dependence on alcohol and pharmacologically active substances as well as the abuse of medicines, even those allowed.

It is therefore necessary to increase the quantity / quality of time devoted to physical activity, both in school and extracurricular.

Basically, fundamental is the knowledge of the problem.

As a first step it is fundamental to know one's Personal Wellness Profile: Biometric screening values, Personal activity status, Exercise and Sedentary Time, Body Measurements \& Health Risk.

The analysis of the body composition is of great help to understand the personal needs. Percent of fat is easily measured by impedentiometry or, more precisely, by DEXA. Impedentiometry furnishes also additional parameters, such as hydratation and Muscular Active Mass. In the following table VIII,

\begin{tabular}{|c|c|c|c|c|c|c|}
\hline \multicolumn{7}{|l|}{ Table VIII. } \\
\hline Women & \multicolumn{5}{|l|}{} \\
\hline Age & $20-29$ & $30-39$ & $40-49$ & $50-59$ & $60-69$ & $70-79$ \\
\hline \multirow{2}{*}{ Good } & $16.8-$ & $17.5-$ & $19.9-$ & $22.6-$ & $23.3-$ & $24.1-$ \\
& 19.4 & 20.8 & 23.8 & 27.8 & 27.9 & 28.6 \\
\hline Men & & & & & \\
\hline Age & $20-29$ & $30-39$ & $40-49$ & $50-59$ & $60-69$ & $70-79$ \\
\hline \multirow{2}{*}{ Good } & $10.6-$ & $14.6-$ & $17.5-$ & $19.2-$ & $19.8-$ & $20.3-$ \\
& 14.4 & 18.2 & 20.6 & 22.1 & 22.6 & 22.1 \\
\hline
\end{tabular}

the desired amount of percent Body Fat in Women and Men is illustrated.

Additional important parameters to assess the status of the subject are the triglyceride levels (Table IX) and fasting glucose (Table IX).

\begin{tabular}{|c|c|}
\hline \multicolumn{2}{|l|}{ Table IX. } \\
\hline Triglyceride Category & Triglyceride Level \\
\hline Normal & $<150 \mathrm{mg} / \mathrm{dL}$ \\
\hline Borderline high & $150-199 \mathrm{mg} / \mathrm{dL}$ \\
\hline High & $200-499 \mathrm{mg} / \mathrm{dL}$ \\
\hline Very high & $\geq 500 \mathrm{mg} / \mathrm{dL}$ \\
\hline
\end{tabular}




\begin{tabular}{|c|c|c|}
\hline \multicolumn{3}{|c|}{ Table X. } \\
\hline Category & Feasurement & \\
\hline Normal & $<100 \mathrm{mg} / \mathrm{dL}$ & $<5.7 \%$ \\
\hline Pre-Diabetes & $100-125 \mathrm{mg} / \mathrm{dL}$ & $5.7 \%-6.4 \%$ \\
\hline Diabetes & $>126 \mathrm{mg} / \mathrm{dL}$ & $>6.5 \%$ \\
\hline & $\begin{array}{c}\text { Note: impaired fasting } \\
\text { glucose should be } \\
\text { confirmed by testing }\end{array}$ & \\
\hline
\end{tabular}

Another fundamental issue concerning physical activity is that it's never too late to start but it's always too soon to quit. We need movement. Becoming active may add 14 extra "healthy years" to our life. Most of what we think of as aging is not aging but disuse... Birth certificates aren't issued with expiration dates [15-17].

But how many people know what we are dealing with now? And what should we do to increase the general physical activity and the number of practitioners?

A comprehensive information / training, along with sporting activities and adequate medical check-ups in every school order, would lead to a sharp reduction in public spending.

The ideal would be to set up a health, nutritional and sports education course in school.

Health education, proper nutrition and sports activities in the school prepare new generations to a lifestyle that generates strong savings for the National Healthcare System.

It is necessary to have appropriately qualified teaching staff for the treatment and dissemination of the principles of health prevention, proper nutrition and the correct approach to sports activities.

It therefore needs specific training.

This means the need of a GLOBAL Education as follows:

- Education of the teachers in the school

- Training of Family Physicians

- Training of Physical and Athletic Training Professionals

- Training of sports executives

- The role of sports managers

Managers are needed not only driven by the achievement of the result, but that make sport a means of improving public health. It is therefore of fundamental importance the definition of the notions necessary for the role of sports manager and related training. An adequate university training is essential for those who want to undertake the Career. At all levels.

The ideal sports manager should have a global knowledge: biomedical, technical for training and rehabilitation, he should have experience in legal and economical affairs, in sports psychology, communication, equipment and installations. Sports managers, very often, are "home made".

For younger generations, which must be geared to a proper culture of sport, it is essential the presence of instructors and executives who are well-versed in knowing what they are doing and of the human resources they have. Trainers should be "certificated".

We know how much a coach counts in a team; he has the role of educator and controller and would be of primary importance to be sure of his quality.

Many organizations also use sports centers for the sale of illicit products and money laundering.

Illegality is favored by underdevelopment and ignorance.

Establishing in every sports center, from the smallest gym to the largest organization, the certified quality of the manager, would not only be a guarantee for the public to have quality instructors, but also the ability to "plot" the system fully, limiting the radius of action of criminal organizations.

\section{The Final Proposal}

To develop, in universities or hospitals, a privileged path for sporting fitness as well as for the diagnosis and treatment of sports-related illnesses through the conduct of sports activities, under control.

Establish MoUs between school and sports facilities to develop low cost physical activity.

The establishment of Centers that deal with all of the above mentioned problems is therefore of great utility and timeliness.

It is necessary to match the academic and scientific capacity of the University to the world of sport, involving the greatest sports worlds: Olympic Committee and Sport Federations, but also public and private bodies, sports clubs, clubs and gyms, for achieving the goals outlined.

Institutions (Ministries, Regions, Provinces, Municipalities), Sports Entities, Military Sports groups,

Manufacturers (Techniques, Sanitary, Pharmaceuticals), Sports Clubs, Gyms.

Our goal must be: Prevention.

\section{References}

1. Lobelo F, Stoutenberg M, Hutber A. The Exercise is Medicine Global Health Initiative: a 2014 update. Br J Sports Med. 2014;48(22):16271633. doi:10.1136/bjsports-2013-093080

2. Pedersen BK, Saltin B.Exercise as medicine - evidence for prescribing exercise as therapy in 26 different chronic diseases. Scand J Med Sci Sports. 2015;25 Suppl 3:1-72. doi:10.1111/sms.12581

3. Lluch A, Herbeth B, Méjean L, Siest G. Dietary intakes, eating style and overweight in the Stanislas Family Study. Int J Obes Relat Metab Disord. 2000;24(11):1493-1499. doi:10.1038/sj.ijo.0801425 
4. Videon TM, Manning CK. Influences on adolescent eating patterns: the importance of family meals. J Adolesc Health. 2003;32(5): 365373. doi:10.1016/S1054-139X(02)00711-5

5. Verna R. The history and science of chocolate. Malays J Pathol. 2013;35(2):111-121.

6. Biro FM and Wien M. Childhood obesity and adult morbidities. Am J Clin Nutr. 2010;91(5):1499S-1505S. doi: 10.3945/ajcn.2010.28701B

7. WHO, 2001. Report on Obesity

8. Banfi G, Dolci A, Malavazos A, Doneda L, Verna R, Corsi MM. Serum oxidant and antioxidant status and presence of nitric oxide and heat shock protein 70 in trained elite soccer players. Eur J Appl Physiol. 2006;96(5):483-486.

9. Verna R, Cama G, Arca M, Corsi MM, D’Onofrio G. Il Laboratorio di Patologia Clinica nell'attività sportiva. Prima parte Cenésthesis 4, 10-19.

10.Verna R, Cama G, Arca M, Corsi MM, D’Onofrio G. Il Laboratorio di Patologia Clinica nell'attività sportiva. Seconda parte. Cenésthesis 5, 36-39.
11.Verna $\mathrm{R}$, Ravazzolo $\mathrm{M}$. La tutela della salute nelle attività sportive e la lotta al doping: nuove opportunità per il patologo clinico. Il Patologo Clinico. 2002;9-12; 384-394.

12.Verna R, Ravazzolo M. Nuove strategie per la tutela della salute nelle attività sportive e per la lotta al doping. Quaderni Fondazione Piaggio, II. 2003;130-160.

13. Katz MH. How can we know if supplements are safe ifwe do not know what is in them?:Comment on "The frequency and characteristics of dietary supplement recalls in the UnitedStates". JAMA InternMed. 2013;173(10):928. doi: 10.1001/jamainternmed.2013.415

14. Koncic MZ, Tomczyk M. New insights into dietary supplements used in sport: activesubstances, pharmacological and side effects. Curr Drug Targets. 2013;14(9):1079-1092.

15.Bortz W. Understanding frailty. J Gerontol A Biol Sci Med Sci. 2010;65(4):382-385. doi: 10.1093/gerona/glp164.

16. Bortz W. Blog, 2012.

17. Peeters G, Dobson AJ, Deegc DH, Brownd WJ (2013). A life-course perspective on physical functioning in women. Bulletin of the WHO 